\title{
7: 45701327-45706499
}

National Cancer Institute

\section{Source}

National Cancer Institute. 7:45701327-45706499. NCI Thesaurus. Code C42520.

Physical location of IGFBP1_Gene 